\title{
Perkembangan Kota Yogyakarta Berdasarkan Peningkatan Pemanfaatan Lahan
}

\author{
Novida Abbas \\ Enny Ratna Dewi
}

Keywords: settlement, city, urban, development, colonial

\section{How to Cite:}

Abbas, N., \& Dewi, E. R. Perkembangan Kota Yogyakarta Berdasarkan Peningkatan Pemanfaatan Lahan. Berkala Arkeologi, 15(2), 25-34. https://doi.org/10.30883/jba.v15i2.658

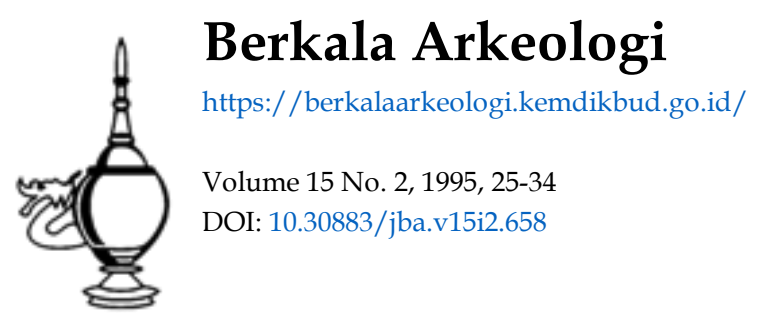

\section{(c) (†) ()}

This work is licensed under a Creative Commons Attribution-NonCommercial-ShareAlike 4.0 International License. 



\title{
PERKEMBANGAN KOTA YOGYAKARTA BERDASARKAN PENINGKATAN PEMANFAATAN LAHAN *
}

\author{
Novida Abbas * \\ Enny Ratna Dewi
}

\section{Pendahuluan}

Tulisan ini mencoba membahas tentang perkembangan Kota Yogyakarta berdasarkan model penggunaan lahan. Perubahan, baik penyusutan maupun perkembangan, jelas merupakan suatu hal yang dialami Kota Yogyakarta, mengingat sampai saat ini keberadaan Kota Yogyakarta telah berlangsung hampir seperempat abad.

Dari sudut penelitian tata kota, hal ini merupakan suatu masalah yang menarik. Perubahan suatu wilayah, seperti perluas an areal, akan mempengaruhi fungsi suatu lokasi, yang terkadang fungsi tersebut dapat saling tumpang tindih (Wibisono, 1986:36). Model-model penelitian mengenai perubahan seperti tersebut di atas, telah banyak diciptakan antara lain berdasarkan data arkeologis maupun historis. Salah satu model penelitian dengan pendekatan pola penggunaan lahan telah dimulai oleh David Clark (1977).

Bagi Situs Yogyakarta pendekatan tersebut dapat diterapkan karena telah banyak sumber yang tersedia. Sumber-sumber yang dianggap dapat memberikan informasi dan gambaran tentang penggunaan lahan serta konteks dan mekanisme kegiatan pemakainya antara lain adalah peta-peta lama Yogyakarta dan sumber sejarah lainnya Dalam kajian ini sebagai sumber data utama digunakan peta-peta tahun $1765,1790,1811,1824,1837,1860,1870,1873,1900,1925$, dan 1945

Peta-peta kuna mempunyai kemampuan memberikan informasi tentang penggunaan lahan masa lampau. Pemanfaatan lahan oleh manusia tentunya dilatarbelakangi oleh hal tertentu. Asumsi tersebut didasari oleh pemikiran bahwa manusia tidak begitu saja menempatkan diri dalam ruang. Mereka mengelompok menempati ruang berdasarkan aktivitas sosial yang dilakukannya ataupun budaya tertentu. Beranjak dari pemikiran tersebut, maka suatu kota dimungkinkan terdiri atas berbagai lokasi atau klaster, yang secara kualitas dan kuantitas

* Pernah disajikan dalam Seminar Sehari Arkeologi Perkotaan sebagi Assei Pariwisata Yogyakarta, 1990

* Balai Arkeologi Yogyakarta

... STUPA (Studio Pariwisata) 
mempunyai perbedaan. Nilai suatu klaster atau lokasi ditentukan oleh keragaman dalam penggunaan lahannya. Lokasi yang memiliki keragaman dalam penggunaan lahan menunjukkan bahwa intensitas aktivitas manusia di tempat itu tinggi

Sebagai sebuah pusat politik, pada awainya Yogyakarta dapat dinyatakan merupakan suatu sistem budaya yang terdiri atas tiga wujud kebudayaan, yaitu sistem gagasan, sosial, dan teknologi. Ketiga sistem tersebut melandasi kehidupan peradaban Kota Yogyakarta. Sistem gagasan yang meliputi ideologi, kesepakatan, dan mental template urbanisasi bersandar pada pemikiran supra empirik jalinan makrokosmos-mikrokosmos. Dalam pemikiran supra empirik tersebut dinyatakan bahwa jagad kecil (mikrokosmos, yaitu di mana manusia hidup) pada dasarnya merupakan replika jagad besar (makrokosmos). Kemakmuran dan ketentraman dapat dicapai manusia dengan jalan menyelaraskan keadaan, yaitu menyusun kerajaan sebagai gambaran alam semesta dalam bentuk kecil (Geldern,1982). Penjabaran tersebut menyangkut aspek fisik maupun non fisik. Aspek fisik antara lain tercermin dalam penataan wilayah kerajaan serta tata bangunan yang ada di dalam kota dan kraton, sedangkan aspek non fisik dapat dilihat dalam wujud sistem sosial yang meliputi institusi dan interaksi sosial.

\section{Penggunaan Lahan}

Sumber data utama tulisan ini adalah peta-peta lama Yogyakarta yang berasal dari masa Sultan Hamengku Buwana I sampai dengan Sultan Hamengku Buwana IX. Selain itu juga digunakan data sejarah yang menyebutkan tentang beberapa bangunan, baik di dalam maupun di luar kraton, serta data toponim yang dapat mendukung peta

\section{Tabel 1. Peta-peta Lama Situs Yogyakarta}

\begin{tabular}{l|l}
\hline $\begin{array}{l}\text { Tahun 1765 } \\
\text { Tahun 1790 }\end{array}$ & Masa pemerintahan Hamengku Buwana I (1755-1792) \\
\hline Tahun 1811 & Masa pemerintahan Hamengku Buwana II (1792-1812) \\
Tahun 1824 \\
Tahun 1837 \\
$\begin{array}{l}\text { Tahun 1860 } \\
\text { Tahun } 1870 \\
\text { Tahun } 1873\end{array}$ & Masa pemerintahan Hamengku Buwana V (1823-1855) \\
\hline $\begin{array}{l}\text { Tahun 1900 } \\
\text { Tahun 1908 }\end{array}$ & Masa pemerintahan Hamengku Buwana VI (1855-1877) \\
\hline Tahun 1925 & Masa pemerintahan Hamengku Buwana VII (1877-1921) \\
\hline Tahun 1945 & Masa pemerintahan Hamennku Buwana VIII (1921-1939) \\
\hline
\end{tabular}


Berdasarkan pengamatan terhadap keseluruhan peta dan keterangan sumber sejarah serta toponim yang dianalisis, maka dapat diketahui pola penggunaan lahan di Kota Yogyakarta dari masa ke masa. Penggunaan lahan menunjuk kelompok atas dasar ras, fungsi. dan jenis kegiatan, yaitu sebagai berikut.
2.1. Tempat tinggal
2.2. Tempat ibadah
2.3. Sarana transportasi
2.4. Pendidikan
2.5. Lokasi hiburan
2.6. Lokasi perdagangan
2.7. Industri.

Gambaran umum penggunaan lahan pada masa-masa pemerintahan para Sultan Yogyakarta seperti tersebut di atas dapat dilihat pada Tabel 2 di belakang. Lokasi lahan dalam hal ini dibedakan menjadi dua, yaitu yang berada di dalam dan di luar benteng kraton.

Pada masa pemerintahan Sultan Hamengku Buwana I para bangsawan yang waktu itu juga menduduki jabatan di pemerintahan bertempat tinggal di dalam lingkungan benteng. Masyarakat menempati perkampungan di seputar benteng, terutama di sisi barat dan timur. Masjid Agung pada masa itu telah berdiri, yaitu di sebelah barat alun-alun Dalam sumber tertulis disebutkan bahwa masjid ini didirikan pada tahun 1773 M (Babad Memana, tanpa tahun. Koleksi Perpustakaan Museum Sonobudoyo No. PBE 100).

Penduduk ras Cina telah bermukim di dekat perkampungan pejabat pemungut cukai (tanda) yang disebut Ketandan. Pada akhirnya kalangan etnis Cina tersebut menempati pula Kampung Ketandan karena keaktifan mereka membayar cukai, dan bahkan jabatan tanda tersebut akhirnya dipegang pula oleh golongan masyarakat ini. Dimanfaatkannya orang-orang Cina sebagai pemungut cukai tidak hanya di kota-kota istana saja, melainkan juga di tempat lain yang memiliki pasar. Sampai saat ini, seperti yang terlihat di Yogyakarta atau Surakarta, Kampung Pecinan terletak berdekatan dengan Kampung Ketandan.

Pasar muncul bersamaan dengan dibangunnya Kraton Yogyakarta. Pasar yang dimaksud adalah pasar kota yang terletak di sebelah utara alun-alun. Wujudnya tentu tidak serupa dengan yang sekarang, karena bentuk yang sekarang telah mengalami perbaikan sejak tahun 1925. 
Kuburan yang pertama terlihat di peta adalah yang berlokasi di sebelah utara Benteng Vredeburg Setelah itu disusul dengan pemanfaatan lahan sebelah timur laut dan timur benteng kraton sisi timur. Pada masa yang sama terdapat pula kuburan orang Cina di sebelah barat laut benteng kraton, tepatnya di lembah Sungai Winongo.

Jalan raya yang sekarang dikenal sebagai poros Yogyakarta telah terlihat pada peta masa Hamengku Buwana |. Hanya saja jalan tersebut masih terbatas sepanjang alun-alun utara menuju Tugu, sedangkan yang dari alun-alun selatan menuju Krapyak belum didapati. Jalan-jalan menuju beberapa tempat penting seperti Kotagede, Parang Kusumo, atau Pesanggrahan Rejowinangun telah ada.

Di dalam lingkungan benteng kraton sendiri keadaan pemanfaatan lahan relatif masih sederhana. Jalan penghubung dari pintu gerbang (plengkung) menuju ke luar benteng belum tersedia, dan masih terbatas pada jalan-jalan di lingkungan dalam benteng saja. Bangunanbangunan di lingkungan kraton yang telah berdiri pada masa pemerintahan Hamengku Buwana I baru terbatas pada Bangsal Pengapit dan Pemandengan di Pagelaran, Tratag Sitihinggil, Bangsal Pancaniti di Keben, Bangsal Srimanganti dan Trajumas, Kraton Kilen/Keputren, Prabayeksa, Ksatrian, Bangsal Kemandungan, dan Bangsal Sitihinggil selatan.

Bangunan Tamansari telah berdiri dengan lengkap pada akhir masa pemerintahan Sultan Hamengku Buwana I. Untuk keperluan suplai air di Tamansari dibuat cabang dari Sungai Winongo yang dikenal sebagai kali Larangan. Air dari Kali Larangan tersebut dialirkan pula ke jagang Masjid Agung dan parit benteng kraton.

Pada masa sultan berikutnya, yaitu Hamengku Buwana II (1792. 1812), praktis tidak banyak perkembangan yang berarti. Hal ini terutama disebabkan karena situasi politik yang tidak menentu pada masa itu, akibat campur tangan pemerintah Hindia Belanda dalam kewenangan kraton. Masa pemerintahan Sultan Hamengku Buwana II diselingi oleh masa pemerintahan Hamengku Buwana III dan Hamengku Buwana IV. Hamengku Buwana II kemudian memusatkan perhatiannya pada pembangunan karya arsitektural berupa pesanggrahan-pesanggrahan, misalnya Rejowinangun, Gedongkuning, Gua Siluman, dan Cendanasari (Dewi,1985). Sementara itu pada masa pemerintaha Hamengku Buwana II kraton sempat pula dirusak oleh tentara Inggris yang dikenal dengan sebutan geger spei (Carey,1986)

Perkembangan yang penting pada masa pemerintahan Hamengku Buwana II adalah munculnya jalan poros dari alun-alun selatan menuju ke Krapyak. Nampaknya pengadaan jalan ini berkaitan 
dengan prosesi jenazah Sultan Hamengku Buwana I dari kraton ke Imogirı melewati Plengkung Gading dan juga pendirian Pesanggrahan Krapyak.

Hunian orang Eropa yang berlokasi di timur Benteng Vredeburg telah muncul dan dikenal dengan sebutan Loji Kecil. Gedung Karesidenan sebagai pusat pengambilan keputusan politik dan militer terletak di sebelah barat Benteng Vredeburg. Kuburan orang-orang Belanda telah muncul pula, yaitu berlokasi di belakang Pasar Gede Jalan-jalan kolektor bertambah, sedangkan jalan regional tetap

Pada masa pemerintahan Sultan Hamengku Buwana $V$ mulai tampak perkembangan yang berarti dalam penggunaan lahan di Kota Yogyakarta lama. Rumah-rumah pejabat dan bangsawan semakin bertambah di dalam maupun di luar benteng. Demikian pula dengan hunian orang-orang Belanda dan Cina. Tangsi-tangsi di sekitar kompleks Gedung Karesidenan pun bertambah.

Jalur-jalur jalan lokal bagian barat dan selatan berkembang, demikian pula jalan-jalan lingkungan. Jalan keliling benteng sebelah dalam didapati pula pada peta dari masa pemerintahan Hamengku Buwana V.

Di sebelah barat laut benteng kraton telah terlihat adanya dalem Pangeran Diponegoro, tepatnya di daerah Tegalrejo. Pada peta tahun 1937 indikasi kompleks bangunan tersebut telah tiada. Ketiadaan ini berkaitan dengan Perang Jawa yang berlangsung tahun 1825-1830 (Carey, 1986). Dalam kerusuhan tersebut Tamansari sisi selatan serta dalem Kadipaten juga rusak.

Pada peta tahun 1873, yaitu dari masa pemerintahan Sultan Hamengku Buwana $\mathrm{VI}$, dalem-dalem pangeran atau bangsawan kraton, baik yang terletak di dalam maupun di luar benteng kraton, telah menyerupai keadaan saat ini. Demikian pula dengan abdi dalem istana yang menghuni kampung-kampung tertentu sesuai dengan tugasnya. Kampung-kampung tersebut pada umumnya berada di dalam benteng, antara lain adalah sebagai berikut

Siliran

Gamelan

Pesindenan

Langenastran

Langenarjan tempat tinggal abdi dalem yang mengelola lampu istana.

tempat tinggal abdi dalem yang mengurus kuda tempat tinggal abdi dalem wirasuara. tempat tinggal korps prajurit Langenastra (kawal istana) tempat tinggal korps prajurit Langenarja (kawal istana) 
Patehan

Nagan

Suranatan tempat tinggal abdi daiem yang mengurus minuman (teh)

tempat tinggal abdi dalem pemain gamelan (niyaga).

tempat tinggal ulama kraton (suranata)

Para abdi dalem yang bertempat tinggal di dalam benteng memiliki kegiatan sehari-hari yang berkaitan erat dengan keperluan kraton

Pada masa pemerintahan Sultan Hamengku Buwana VI telah ada stasiun kereta api yang berlokasi di Lempuyangan. Stasiun dan rel kereta api dibangun sejalan dengan tuntutan kegiatan produksi gula pada pabrik-pabrik yang didirikan oleh orang-orang Belanda. Pabrikpabrik gula tersebut berkembang terutama di sebelah barat dan selatan kota, di antara perkebunan-perkebunan tebu yang potensial di masa itu. Bahkan pada masa pemerintahan Sultan Hamengku Buwana VII jumlah pabrik gula mencapai 17 buah. Transportasi kereta api pun mencapai kawasan pelosok di sebelah selatan dan barat Yogyakarta.

Prasarana kereta api pada masa pemerintahan Hamengku Buwana VII meluas tidak hanya untuk kepentingan pabrik gula semata, namun juga dibangun ke barat sampai Maos dan Cilacap untuk kepentingan umum. Sarana di Yogyakarta yang melayani kepentingan ini adalah sebuah stasiun yang terletak di sebelah selatan Tugu, yaitu Stasiun Tugu. Sarana transportasi ini dikelola oleh Staatsspoorwegen (SS).

Stasiun untuk penumpang yang terdiri dari pedagang kecil dari Pasar Beringharjo dibangun lagi di Ngabean. Sementara itu jaringan hubungan kereta api jenis trem dibangun pula ke arah utara untuk memenuhi kebutuhan pabrik gula yang berada di bagian barat (Beran, Medari, dan sebagainya). Pembukaan jalur transportasi kereta api ke Magelang tersebut telah merangsang pula pembukaan pemukiman dan kegiatan ekonomi di utara, dalam hal ini pemukiman Cina di kawasan Kranggan dan sekitarnya. Pada tahun 1919 dibuka lagi jalur rel ke selatan melalui Kotagede dan Plered, yang dikelola oleh Nederlandsch-Indische Spoorwegmaatschappij (NIS).

Pada masa itu muncul juga Gereja Protestan di depan pasar, sekolah Gupermen, Hotel Tugu, Hotel Mataram (sekarang Hotel Garuda), Javaansche Bank, Rumah Sakit Bethesda, penjara Wiragunan, kantor pos, museum, dan arena pacuan kuda. Arena pacuan kuda tersebut, yang berlokasi di Balapan sekarang, tidak didapati lagi pada peta tahun 1945 
Pada masa pemerintahan Sultan Hamengku Buwana VIII dan IX. sebagaimana tampak pada peta tahun 1924 dan 1945, terlihat bahwa dalem pangeran dan pejabat istana mengalami penyusutan dibandingkan masa sebelumnya. Beberapa yang masih tersisa antara lain Mangkubumen, Brontokusuman, Danurejan, Purwodiningratan, Kumendaman, Brontodiningratan, serta Ngadiwinatan

\section{Risalah}

Secara kualitatif, pemanfaatan lahan sejak fase Sultan Hamengku Buwana I sampai dengan VI tidak memperlihatkan perbedaan yang berarti, walaupun secara kuantitatif perbedaan tersebut tampak jelas. Perbedaan tersebut terutama tampak pada perluasan pemukiman, baik di dalam benteng dan terlebih di luar benteng. Perkembangan kualitatif dan kuantitatif yang menonjol terlihat jelas pada masa pemerintahan Sultan hamengku Buwana VII. Sementara itu pada masa sesudahnya terjadi beberapa gejala penyusutan, terutama pada fasilitas yang merupakan bagian dari gaya hidup kalangan atas.

Pertumbuhan pemukiman di Yogyakarta mengikuti pola yang berbeda-beda, sesuai dengan orientasi dan kepentingan kelompok penghuninya. Pemukiman kalangan pribumi pada awalnya membentuk deliniasi yang berorientasi kuat pada kekuasaan (kraton), sehingga perkampungan pribumi pada awalnya berkembang di seputar benteng kraton (Bintarto, 1984). Perkembangan lokasi pemukiman pribumi yang menjauh dari benteng kraton disebabkan oleh penempatan dalemdalem pangeran atau pejabat istana yang bertempat di luar benteng. Namun demikian perkembangannya secara spasial masih memperlihatkan orientasi konsentris, mengingat penempatan dalemdalem pangeran tidak lepas dari hubungannya dengan kraton sebagai pencerminan konsep jagad agung dalam tata ruang masyarakat Jawa.

Di lain pihak pemukiman kalangan etnis Cina memperlihatkan orientasi yang berbeda dengan kalangan pribumi, dalam hal ini kalangan Cina lebih berorientasi ekonomis. Pemukim Cina pada awalnya menempati lahan di seputar pasar dan percukaian. Dengan perluasan fungsi jalan poros alun-alun utara ke Tugu (Malioboro), dari fungsi magis ke fungsi ekonomis, maka pemukim Cina pun pada akhirnya menempati tepi kiri-kanan jalan poros tersebut. Potensi interaksi ekonomis eksternal ke belahan Jawa Tengah bagian utara (Magelang dan Semarang) mendorong pula perluasan pemukiman Cina ke kawasan utara Yogyakarta 
Pemukıman Belanda di satu pihak nampak menganut orientasi politik dan militer yang bersifat konfrontatif dengan pihak kraton. Orientasi eksternal pihak kraton ke arah utara - sementara itu arah selatan merupakan orientasi yang lebih bersifat privacy - merupakan sasaran 'gangguan' kalangan Belanda di Yogyakarta pada masa lampau. Dengan demikian penempatan pusat-pusat aktivitas politik dan militer, dan bahkan aktivitas ekonomis pada masa yang kemudian, ditempatkan pada jalan poros alun-alun utara ke Tugu. Hal itu diwujudkan dalam bentuk pembangunan Benteng Vredeburg dan Gedung Karesidenan di sebelah utara kraton, tepat mengapit jalan poros ke Tugu. Pada masa yang kemudian intensitas 'gangguan'-nya meningkat dalam wujud pendirian bangunan masif berupa fasilitas bank dan pos tepat di utara alun-alun utara.

Sementara itu pada aspek yang lain, pemukiman Belanda pada umumnya memperlihatkan kecenderungan menjauh dari pusat aktivitas politik dan militer. Dari kawasan Loji Kecil di timur Benteng Vredeburg, pemukiman Belanda lainnya tumbuh di sebelah timur Sungai Code, tepatnya di daerah Bintaran. Perluasan berikutnya menempati lokasi di daerah Kota Baru, yang dilengkapi pula oleh fasilitas rumah sakit, yaitu RS Bethesda.

Fasilitas umum seperti tempat ibadah, pasar, dan kuburan berkembang selaras dengan pertumbuhan dan perluasan pemukiman manusia. Hal ini berlaku baik pada pemukiman pribumi, Cina, maupun Belanda. Namun pada saat ini beberapa fasiitas umum tersebut telah mengalami reduksi ataupun berubah fungsi sesuai dengan tuntutan zaman. Dengan demikian kuburan dari periode awal Yogyakarta di utara Benteng Viredeburg misalnya, telah tidak berfungsi lagi, sebagaimana juga beberapa jalur rel kereta api yang menuju ke utara dan selatan Yogyakarta. 


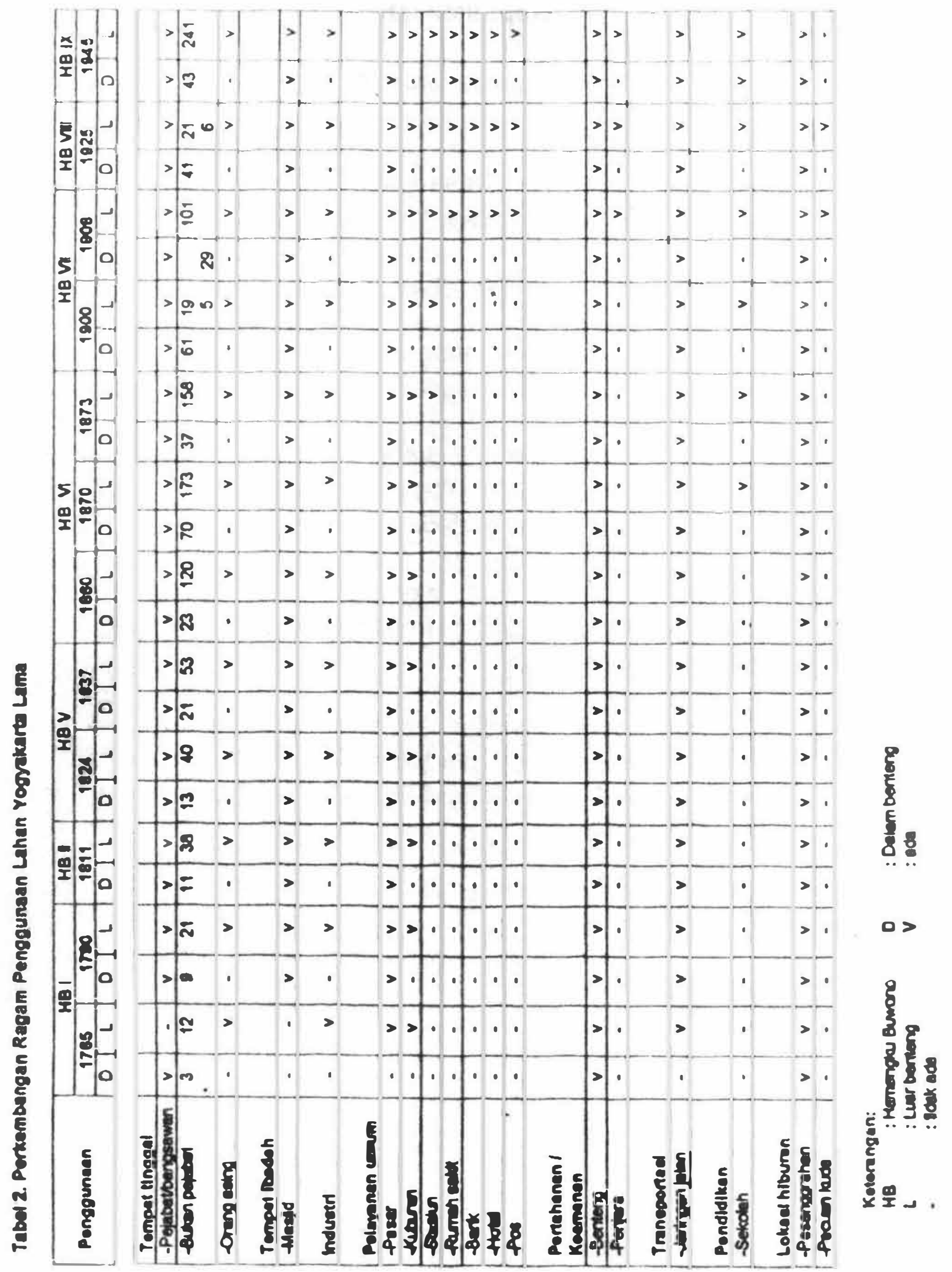




\section{Kepustakaan}

Babad Memana. Koleksi Perpustakaan Museum Sono Budoyo No PBE 100

Bintarto, R 1984. Interaksi Desa-Kota dan Permasalahannya Yogyakarta: Ghalia Indonesia.

Carey, Peter. 1986. Asal-usul Perang Jawa Jakarta: Pustaka Azet

Clark, David. 1977. Spatial Information in Archaeology, dalam Spatial Archaeology. New York: Academic Press.

Dewi, E. R. (1985). Bentuk Lengkung Pada Pesanggrahan-Pesanggrahan Kesultanan Yogyakarta (Tinjauan Arsitektur Berdasarkan Bentuk, Fungsi, Konstruksi dan Simbol). Berkala Arkeologi, 6(2), 61-69. https:/l doi.org/10.30883/jba.v6i2.444

Heine-Geldern, Robert von. 1982. Konsepsi tentang Negara dan Kedudukan Raja di Asia Tenggara (alih bahasa oleh Deliar Noer). Jakarta: Rajawali.

Universitas Gadjah Mada, Bagian Arsitektur Fakultas Teknik dan Departemen PU Dirjen Cipta Karya Ditaba, 1971. Yogyakarta, Penentuan Awal Tata Kota, SImposium Perencanaan Kota. Yogyakarta.

Wibisono, Sonny Chr 1988. Pola Penggunaan Lahan dan Sejarah Perkembangan Kota Banten Lama, Rapat Evaluasi Hasil Penelitian Arkeologi III. Jakarta: Pusat Penelitian Arkeologi Nasional. 